\title{
Tvorba podzemní vody v okrajových částech Prahy
}

\section{JOSEF VOJTĚCH DATEL, ANNA HRABÁNKOVÁ, LUDĚK STROUHAL}

Klíčová slova: podzemní voda - infiltrace - Praha - urbanizace

\section{SOUHRN}

Podzemní voda je nedílnou součástí hydrosféry a hydrologického cyklu ve zdravé krajině, která je schopna lépe odolávat hydrologickým extrémům, jako jsou povodně nebo dlouhodobé sucho. Hlavním zdrojem podzemní vody jsou srážky. V urbanizovaných oblastech je řada překážek pro infiltraci srážek - městská a průmyslová zástavba a také zvětšující se plochy s nepropustným povrchem. Cílem článku je upozornit na důležitost podzemní vody i v městské krajině a na možná opatření k podpoře infiltrace srážek.

Výzkum proběhl v několika pilotních povodích vnějši Prahy, kde dochází k intenzivnímu rozšiřování zástavby, což je doprovázeno nižší infiltrací srážek ve srovnání s volnou krajinou. Na základě hodnocení pedologických, geologických a hydrogeologických poměrů byla vypracována metodika hodnocení vhodnosti území k infiltraci. Na jejím základě vznikly dva druhy map: mapa infiltračního potenciálu hodnotící především propustnost pưdního a horninového prostředí a dále mapa infiltrační kapacity, navíc zdůrazňující velikost volného zásobního objemu pro vsakovanou vodu. Mapy jsou k dispozici pro prohlížení v mapové aplikaci na stránkách projektu heis.vuv.cz/projekty/ praha-adaptacniopatreni.

Pracovat s těmito mapami je vhodné v kombinaci s aktuální mapou zástavby nebo mapou komplexního využití krajiny, a to za účelem volby optimálního opatření k podpoře infiltrace srážek do podzemních vod $v$ dané oblasti. Tato opatření zahrnují ochranu ploch se zvýšenou vhodností pro infiltraci srážek před zástavbou, omezování odvodu srážek deštovou kanalizací, diferencovanou podporu vsakování srážkových vod (např. ze střech) podle infiltrační vhodnosti různých ploch apod.

\section{ÚVOD}

Podzemní voda je nedílnou součástí hydrosféry i celého životního prostředí. Je velmi důležitým zdrojem kvalitní pitné vody a závisí na ní i cenné vodní a na vodu vázané ekosystémy. Množství a kvalita podzemní vody je v současné době ovlivňována změnami klimatických poměrů a různými zásahy člověka do prírodních podmínek území. Jedním ze znaků zdravé krajiny je i dobře fungující hydrologický cyklus a s ním spojená odolnost vůči různým klimatickým extrémům (období sucha, povodně). Schopnost krajiny k infiltraci významné části srážek do podzemních vod snižuje rizika a dopady povodňových situací a dostatek podzemní vody v krajině významně pomáhá překlenout období sucha.

Urbanizovaná území - at už ve formě městské, nebo průmyslové zástavby se vesměs vyznačují negativními dopady na celý hydrologický cyklus a zvláště na množství a kvalitu podzemní vody. Budovy a zpevněné plochy omezují vsak srážek pod povrch terénu, podzemní stavby a inženýrské sítě uměle odvodňují území a snižují hladinu podzemní vody, v urbanizovaném území je množství potenciálních zdrojů znečištění, jež mají dopad na kvalitu a čistotu povrchových i podzemních vod [1]

Postupně se zlepšující péče o povrchové vody ve městě (různé projekty revitalizace a renaturace toků a nádrží, omezování úniků znečištujuících látek) přirozeně přispívají i ke zlepšování stavu podzemních vod. Vedle toho je však třeba věnovat pozornost některým speciálním aspektům, typickým jen pro péči o podzemní vody, jako jsou např. zvýšená podpora infiltrace srážek ve vhodných místech, kde se vyskytuji propustné horniny, nebo péče o prameny a studánky.

Cílem článku je - na základě výzkumu realizovaného v oblasti vnější Prahy, kde dochází k intenzivní zástavbě dosud volných ploch - upozornit na tyto aspekty výskytu a tvorby podzemní vody ve městech a podpořit procesy, které i v zastavěné krajině mohou přispět k lepší funkčnosti hydrologického cyklu a omezení negativních dopadů spojených s hydrologickými extrémy.

Výskyt podzemní vody a její tvorba ve formě infiltrace srážek závisí ve významné míre na vyskytujících se horninách v dané oblasti (vedle půdních poměrů, srážek, dalších klimatických parametrů a antropogenního využití území). Znalosti geologických poměrů jsou proto předpokladem hodnocení vhodnosti krajiny k infiltraci.

\section{GEOLOGICKÉ POMĚRY VNĚJŠí PRAHY}

Geologický vývoj v oblasti hlavního města Prahy probíhá téměř tři čtvrtě miliardy let - od starohor až po současnost - a tomu odpovídá i velká pestrost horninového podloží. Území leží ve střední části Českého masivu a spadá do středočeské oblasti (bohemikum). Nejstarší geologický podklad území Prahy tvoři horniny svrchního proterozoika a paleozoika (ordovik). Litologicky jde o tmavé břidlice s polohami drob, slepenců a silicitů, v ordovických břidlicích se vyskytují i polohy křemenců a pískovců. Mladší paleozoikum je zastoupeno silurem a devonem. Od jihozápadu přes Radotín a Slivenec až do Hlubočep a Prokopského údolí zasahují silurské a devonské vápence (v nichž najdeme i vrstvy břidlic), jež se dostávají až na pravý břeh Vltavy v Podolí a Braníku. Horniny jsou tektonicky postiženy (vrásnění, zlomy, přesmyky) a protnuty četnými tělesy vulkanitů. [2]

Tento starý podklad je částečně prekryt pokryvnými útvary svrchní křídy, terciéru a kvartéru. Od severu do Prahy zasahuje okraj české křídové pánve. Dnešní rozšiření svrchnokřídových sedimentů na území Prahy je výsledkem terciérní a kvartérní denudace (eroze a odnosu dřive usazených hornin). Proto se $v$ Praze zachovaly jen nejstarší svrchnokřídové horniny pískovce cenomanu a $v$ jejich nadloží převažující slínovce (opuky) spodního a streedního turonu. Najdeme je na plošinách tvořících nejvyšší místa Prahy (Letňany, Prosek, Bílá hora, Vidoule, Petřín aj.). 
Sedimenty mladšího terciéru jsou místy zastoupeny říčními sedimenty (písky, štěrky, jíly). Odkazují na zcela jinou říční sít, než máme dnes. Najdeme je vysoko nad dnešními údolími, např. u Bílé hory nebo pod Ládvím. Kvartér, tedy nejmladší geologické období, je zastoupen sedimenty většinou říčního (fluviálního) původu, které vytvářejí štěrkopískové výplně údolí kolem řek. Ve vyšších částech území jsou zachovány ve formě denudačních zbytků vyšších (starších) teras, které jsou dokladem intenzivního zahlubování toků během kvartéru, kdy vznikla dnešní krajina se zahloubenými údolími vodních toků (určující drenážní bází je údolí Vltavy) a vyvýšenými plošinami, jež tvoří dưležitou část území vnější Prahy. Nejvýznamnější říční uloženiny souvisejí s největšími toky na území Prahy (Vltava, Berounka), mocnost sedimentů údolní terasy činí až 10-12 m. Fluviální sedimenty kolem menších toků mají menší mocnost, jsou špatně vytříděné a obsahují více jílovité složky. Činností větru místy vznikly i polohy spraší, najdeme je hlavně v západní části Prahy. Velký lokální význam mohou mít v Praze i antropogenní uloženiny (navážky, skládky), které souvisejí s intenzivním využíváním území člověkem. [3]

Nejméně propustné jsou svrchnoproterozoické a paleozoické břidlice, ty jsou pro podzemní vodu propustné jen po málo četných puklinách. Jde o prostředí nepříznivé pro infiltraci srážek a povrchové vody. Relativně více puklin vhodných pro proudění podzemní vody najdeme $v$ ordovických pískovcích a křemencích, které tvoři v převládajících břidlicích různě velké polohy. $\checkmark$ místech svého výskytu tak vytvářejí trochu příznivější prostředí pro infiltraci. $\checkmark$ paleozoických vápencích se vyskytuje puklinově-krasová propustnost; protékající voda vápenec rozpouští, horniny jsou dobře krasově propustné. Jde o příznivé prostředí z hlediska infiltrace. Svrchnokřídové pískovce mají velkou průlinovou až průlinově-puklinovou pórovitost a velmi dobrou propustnost, jsou prostředím velmi vhodným pro infiltraci. V jejich nadloží se vyskytují turonské slínovce a s ohledem na vysokou míru rozvolnění a zvětrání bývají při povrchu silně rozpukané, jejich infiltrační potenciál proto také bývá dost dobrý. Štěrkopískové sedimenty fluviálního původu (vytvářející údolní i vyšší terasy) jsou obvykle velmi dobře průlinově propustné horniny, jež vytvářejí velmi vhodné prostředí pro infiltraci. Jejich propustnost se liší podle zrnitostního složení a podílu jílových částic, která je vyšší u malých tokủ. Lokálně je infiltrace do štěrkopískových sedimentů ztížena méně propustnými vrstvami při povrchu náplavové hlíny, sprašové vrstvy apod. Při technických řešeních k podpoře infiltrace je důležité vsakovací prvky umístovat do hloubky až pod tyto méně propustné polohy. [4] [5]

Podle hydrogeologických poměrů se vymezují oblasti s podobným charakterem výskytu a proudění podzemní vody. ČR byla rozdělena do 152 oblastí, jež se nazývají hydrogeologické rajony [4]. Používají se pro výpočty hydrologické bilance a velikosti zdrojů podzemní vody. Na území Prahy zasahují celkem tři hydrogeologické rajony (obr. 1), přičemž podzemní voda v pokryvných útvarech (fluviální náplavy Vltavy, Berounky a dalších toků) je brána jako součást těchto hydrogeologických rajonů, i když tato poříční voda má částečně samostatný režim. Hydrogeologický rajon 6250 s názvem „Proterozoikum a paleozoikum v povodí př́toků Vltavy“ zahrnuje většinu plochy Prahy s málo propustnými břidlicemi a má nejmenší prírodní zdroje podzemní vody (cca 0,5 l/s/ $\left.\mathrm{km}^{2}[5]\right)$. Na severovýchod zasahuje rajon 4510 „Kř́ida severně od Prahy" s pískovci a slínovci okraje české křídové pánve (přírodní zdroje ve výši kolem $1 \mathrm{l} / \mathrm{s} / \mathrm{km}^{2}$ [5]). Na jihozápadě je pak rajon 6240 „Svrchní silur a devon Barrandienu“ s vápenci, jenž má největší prírodní zdroje podzemní vody v Praze (2-3 l/s/ $\left.\mathrm{km}^{2}[5]\right)$.

Zástavba a velká plocha nepropustných povrchů $v$ městském prostředí významně omezují tvorbu prírodních zdrojů podzemní vody; podle intenzity urbanizace se výše uvedené hodnoty přírodních zdrojů dále zmenšují, např. ve vnitřní Praze na méně než polovinu uváděných hodnot, platných pro volnou krajinu. Bylo by velmi prínosné, kdyby se v oblasti vnější Prahy podařilo přijmout taková opatření k podpoře infiltrace, aby se prírodní zdroje v území s intenzivně pokračující urbanizací udržely blízko svých původních hodnot.

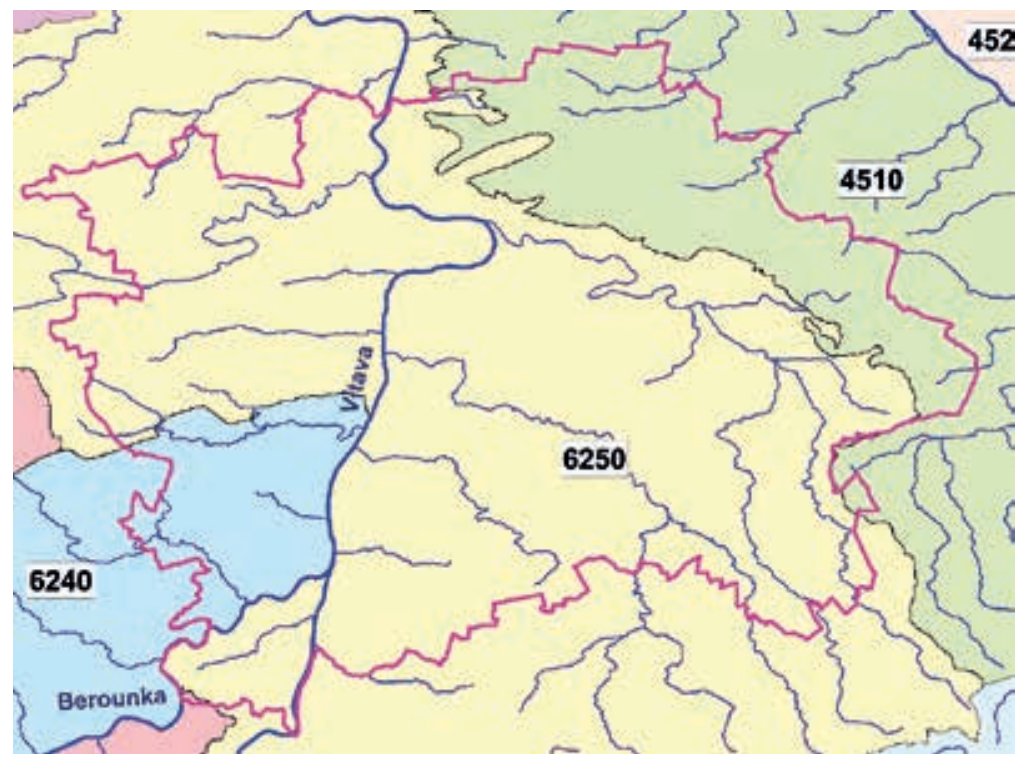

Obr. 1. Hydrogeologické rajony zasahující na území Prahy. Hranice Prahy je zobrazena červenou linií [6]

Fig. 1. Hydrogeological zones in the territory of Prague. The border of Prague is shown by a red line [6]

Pro infiltraci jsou nejvhodnějším prostředím vápence, pískovce a štěrkopísky kolem vodních toků, naopak nejméně vhodným prostředím jsou svrchnoproterozoické a paleozoické břidlice. Vysoká infiltrační schopnost vápenců je doprovázena jejich vysokou zranitelností vưči znečištění. Kontaminant společně s infiltrující vodou může velmi rychle proniknout do podzemí, umělá podpora infiltrace zde proto musí brát v úvahu i tato zvýšená rizika. [1] [7]

\section{INFILTRAČNÍ VLASTNOSTI PŮD}

Pro infiltraci srážek je důležitá i funkce půdního pokryvu, tedy do jaké míry pomáhá, nebo naopak znesnadňuje infiltraci srážek do podzemní vody. K hodnocení půd byla použita klasifikace tzv. hydrologických skupin půd [8]. Půdy podle svých hydrologických vlastností rozděluje do čtyř skupin A, B, C, D na základě minimální rychlosti infiltrace vody do půdy bez pokryvu po dlouhodobém sycení. Infiltrační schopností půd je schopnost povrchu pưdy pohlcovat vodu. Z hlediska vhodnosti pro infiltraci platí, že čím vyšší je infiltrační schopnost půdy, tím vyšší je infiltrace srážek do podzemní vody. Je to hodnocení odlišné od zemědělského hodnocení půd, protože v půdách s nejvyšší infiltrační schopností hrozí nebezpečí rychlého vysoušení pưd a také nežádoucího transportu živin do hlubšího podloží a do podzemních vod.

Infiltrační schopnost půd je syntetický parametr, který je v čase proměnný, jelikož na něj působí řada vlivů - klimatické poměry (srážky, teplota), fyzikální vlastnosti půd (zrnitost, struktura, pórovitost, složení), vodní poměry půd (vlhkost, hydraulická vodivost, vysoká hladina podzemní vody) a dále oživení půdy související s využitím území (rostlinný pokryv, hloubka a charakter kořenového systému, výskyt půdních živočichů aj.). Hydrologické skupiny půd charakterizují půdu s ohledem na dobu hodnocení a použité měřítko.

Skupina A zahrnuje půdy s vysokou rychlostí infiltrace (>0,20 mm/min) - hluboké, dobře až nadměrně odvodněné písčité půdy na pískovcích, píscích a štěrcích. Do skupiny B patří půdy se střední rychlostí infiltrace $(0,10$ až 0,20 mm/min) - půdy středně hluboké až hluboké, středně až dobře odvodněné, hlinitopísčité až jílovitohlinité. Skupina C obsahuje půdy s nízkou rychlostí infiltrace (0,05 až 0,10 mm/min) půdy jílovitohlinité a půdy s málo propustnou vrstvou v půdním profilu. 
A skupina D zahrnuje půdy s velmi nízkou rychlostí infiltrace $(<0,05 \mathrm{~mm} / \mathrm{min})$ jílovité půdy a jíly, zamokřené půdy s trvale vysokou hladinou podzemní vody či mělké půdy s nepropustným podložím těsně při povrchu. [8] [9]

Z hlediska vhodnosti k infiltraci jsou nejvhodnější hydrologické skupiny půd $A$ a $B$, skupina $C$ je méně vhodná a skupina $D$ vymezuje území nevhodné pro infiltraci z povrchu.

\section{METODICKÝ PŘÍSTUP K HODNOCENÍ VHODNOSTI URBANIZOVANÉHO ÚZEMÍ K INFILTRACI}

Při definování parametrů, jež jsou určující pro hodnocení vhodnosti území k infiltraci, bylo zjištěno, že jsou velmi podobné parametrům používaným pro stanovení zranitelnosti podzemních vod z hlediska průniku znečištění z povrchu do podzemní vody. Jejich význam je však třeba většinou chápat inverzně území označené jako nejvíce zranitelné je zároveň velmi vhodné pro infiltraci a naopak, území málo zranitelné je obvykle i nevhodné k infiltraci vody pod povrch území. Úspěšně tedy bylo možné navázat na provedené výzkumy týkající se zranitelnosti podzemních vod vůči znečištění. Specifickým souhrnným parametrem $v$ urbanizovaném prostředí je pak informace o intenzitě a charakteru zástavby, jak je uvedeno dále.

Je třeba také upozornit na skutečnost, že jak zranitelnost, tak vhodnost k infiltraci se hodnotí v rámci zájmového území v relativních kategoriích. To je dáno účelem těchto hodnocení - definovat ty oblasti, kde je vhodnost - a tím i efektivnost opatření k podpoře infiltrace - relativně největší a kde je naopak nejmenší; a podobně je to i se zranitelností. Tyto informace Ize pak účinně používat v řizeném využívání území, v omezování nepropustných ploch v zónách s vysokou infiltrací, ve větší podpoře zasakovacích prvků v oblastech s lepšími infiltračními parametry, v optimálním umístování environmentálně rizikových provozů, ve směřování zástavby do území s menšími dopady na hydrologický cyklus krajiny atd. Mapy zranitelnosti podzemních vod i mapy vhodnosti plochy k infiltraci tak území rozdělují do několika tříd, které jsou syntetickým pohledem při započtení relevantních hodnocených parametrů.

\section{VYUŽITÍ METOD HODNOCENÍ ZRANITELNOSTI PODZEMNÍ VODY}

Pojem zranitelnosti podzemních vod se poprvé objevuje již u Margata [10], jenž $\vee$ rámci konstrukce map ochrany podzemní vody vymezil tzv. zranitelná území, kde kontaminace snadno pronikne z povrchu do podzemní vody. $\checkmark$ jeho pojetí zranitelnost podzemních vod úzce souvisí s existencí prirozených ochranných vrstev mezi povrchem území a hladinou podzemní vody. Přirozená ochrana kolektorů podzemních vod je tak tvořena nadložními horninovými a půdními vrstvami (krycí ochranné vrstvy) a jejich vlastnostmi. Podle charakteru těchto vrstev, které určují, jak snadno a jak rychle kontaminující látka z povrchu pronikne do podzemní vody, se hodnotí riziko zranitelnosti podzemní vody. Teoretické aspekty tohoto přístupu byly dále rozpracovány v průběhu 70. a 80. let v řadě publikací; zásadní shrnutí obsahuje jednak manuál US National Research Council [11] a pak práce Vrby a Zaporozce [12], jež shrnuje výsledky práce Komise pro ochranu podzemních vod Mezinárodní asociace hydrogeologů (IAH), především různé příklady z praxe, a také obsahuje doporučenou legendu pro mapy zranitelnosti podzemních vod.

Při hodnocení zranitelnosti hraje významnou roli měřítko zpracování a měřítko dostupných podkladů. Zatímco detailní hodnocení zranitelnosti na malé ploše předpokládá znalost preferenčních cest průsaku a proudění (půdní edafon, pukliny, propustné vrstvy a horizonty apod.), při regionálním hodnocení jsou důležité zprůměrované hodnoty hydraulických parametrů a litologických popisů a záleží na odborné erudici zpracovatelů mapy zranitelnosti, do jaké míry považují za potřebné se věnovat i identifikaci heterogenit rưzného původu, měřitka a významu, a jejich zahrnutí do výstupů.

Nejrozšířenější metodu ve světě, používanou k hodnocení zranitelnosti podzemních vod, vyvinul pro US EPA Aller et al. [13] [14], který definoval sedm hlavních parametrů zranitelnosti podzemních vod:

- D hloubka hladiny podzemní vody (depth to water)

- R dotace podzemní vody ze srážek (recharge)

- A charakter saturované zóny (aquifer media)

- S charakter půdního pokryvu (soil media)

— T morfologie terénu (topography)

- I charakter nesaturované zóny (impact of vadose zone)

- C hydraulická vodivost (conductivity)

Jejich význam se hodnotí ve škále od 1 do 10, kdy 10 znamená nejvyšší zranitelnost. Každý parametr má navíc svoji váhu v hodnotách od 1 do 5.

Během let se vytvořila v různých zemích řada modifikací modelu DRASTIC, nastavení parametrů a volba jejich váhy se může lišit v závislosti na místních podmínkách (různé hydrogeologické, klimatické, litologické a pedologické poměry). V České republice byla tímto prístupem v roce 2012 vytvořena syntetická mapa zranitelnosti podzemních vod ČR v měřítku 1: 50000 [15]. Je také vhodné uvést, že aplikace modelu DRASTIC převažuje do měřitek 1: 50000 a menších, pro detailní hodnocení menších území je většinou třeba větší modifikace a úpravy celého systému (významnější dopad heterogenit všeho druhu).

Vrba a Zaporozec [12] upozorňují na zpracovatelskou složitost celého systému a navrhli ho zjednodušit definováním čtyř hlavních atributů ovlivňujících zranitelnost podzemních vod. Jsou jimi půda, nesaturovaná zóna, saturovaná zóna a dotace kolektoru; za vedlejší atributy označují topografii (morfologie terénu), podloží kolektoru a interakci podzemní a povrchové vody.

\section{VHODNOST ZASTAVĚNÉHO ÚZEMÍ K INFILTRACI}

$\checkmark$ ČR poprvé aplikoval metodický prístup z map zranitelnosti na vhodnost území k infiltraci Hrkal [16], jenž v roce 2010 zpracoval celé území ČR, ale jen ve velmi přehledném měřítku 1: 500000 a bez zřetele k urbanizaci území.

Metodické přístupy použivané pro hodnocení zranitelnosti podzemních vod byly experimentálně ověřeny na šesti povodích v oblasti vnější Prahy, které byly součástí výzkumného projektu Analýza adaptačních opatření ke zmírnění dopadů změny klimatu a urbanizace na vodní režim v oblasti vnější Prahy, řešeného v rámci Operačního programu Praha - pól růstu ČR. Jde o povodí následujicích drobných pražských toků:

- Kopaninský potok

- horní povodí Motolského potoka (po Motolské rybníky)

- Dalejský potok

- Lipanský potok

- Drahanský potok

- Vinořský potok

Povodí byla zvolena tak, aby reprezentovala různá prírodní prostředí oblasti vnější Prahy i odlišný charakter a intenzitu zástavby, aby bylo možné získané zkušenosti a postupy metodicky aplikovat na celé její území. K posouzení jednotlivých parametrů z modelu DRASTIC bylo využito následujících dostupných podkladů:

— inženýrskogeologické mapy Prahy v měřítku 1:5000 (horninové poměry, hloubka hladiny podzemní vody) [17]

— klimatické a bilanční údaje ČHMú (dotace podzemní vody ze srážek) 
— geologické mapy 1:50 000 GeoČR50 [18] a vrstva Charakter horninového prostředí syntetické mapy zranitelnosti [15] (charakter saturované a nesaturované zóny)

— hydrologické skupiny půd (charakter půdního pokryvu) [9]

— topografická mapa [19] (morfologie terénu)

- vrstva transmisivity hornin syntetické mapy zranitelnosti [15] (propustnost hornin)

Vzhledem k tomu, že část map byla k dispozici jen v rastrové formě (inženýrskogeologická mapa, hydrogeologická mapa), jejich využití bylo omezené Jelikož se jako nezbytné ukázaly informace o hloubce hladiny podzemní vody, tento údaj byl $v$ ploše pilotních území zdigitalizován a doplněn o poznatky z terénní rekognoskace území.

Z analýzy použitelnosti metodiky DRASTIC (s ohledem na doporučený př́stup podle návrhu [12]) pro hodnocení infiltračního potenciálu v území vnější Prahy vyplynuly následující závěry a doporučení:

1. Znalost hloubky hladiny podzemní vody je zásadní, protože (společně s pórovitostí hornin) určuje velikost zásobního prostoru pro infiltrovanou vodu. Tento parametr je nezbytné v zájmovém území znát s presesností vyplývající z měřítka zpracování. Pro parametr platí úměra: čím hlouběji se nachází hladina podzemní vody, tím vyšší vhodnost území k infiltraci. Je většinou postačující vycházet z průměrné hloubky hladiny podzemní vody pod povrchem území. V některých územích s velkým rozkyvem hladiny (netýká se pilotních území vnější Prahy) podzemní vody (obvykle na rozvodnicích v územích s velkým sezonním kolísáním srážek) je však užitečná i znalost maximální úrovně hladiny, protože ta v určitých obdobích může významně snižovat objem zásobního prostoru. V rámci hodnocení pilotních povodí byl parametr hloubka hladiny zahrnut ve formě tř́ intervalů prüměrných hloubek: 0-2 $\mathrm{m}$ pod povrchem, 2-6 $\mathrm{m}$ a více než $6 \mathrm{~m}$ pod povrchem.

2. Variabilnost srážek je důležitý parametr pro hodnocení infiltrace ve velkých územích s variabilní morfologií a nadmořskou výškou, protože množství srážek (potažmo efektivních srážek, tzn. srážek po odečtení výparu) primárně určuje velikost infiltrace do podzemní vody. V oblasti vnějši Prahy je však tento parametr monotónní bez významnějších plošných změn, což souvisí s podobnou morfologii (pozůstatek ploché paroviny rozčleněné údolími vodních toků) i podobnou nadmořskou výškou relativně nevelkého území. Pro hodnocení relativních změn v infiltračním potenciálu proto tento parametr nebyl dále zvažován.

3. Charakter saturované a nesaturované zóny se v jednotlivých pilotních povodích prakticky shodoval, tyto dva parametry jsme proto sloučili do jednoho. Z charakteru vyskytujících se hornin navíc vyplývá i jejich propustnost, proto byl tento parametr rovněž zahrnut do jedné vrstvy charakteru horninového prostředí. Vrstva charakteru horninového prostředí zahrnující tyto údaje rozděluje území do pěti kategorií podle potenciálu k infiltraci [15]. Nejlépe propustné horniny mají vysoký potenciál k infiltraci (pískovce, štěrkopísky) a naopak horniny typu břidlic a jílovců mají tento potenciál nízký.

4. Pro infiltraci prímo z povrchu území má důležitý význam charakter půdního pokryvu. Jeho význam klesá v prípadech, že nehodnotíme príirozenou infiltraci z povrchu, ale infiltrační potenciál podpořený technickými zasakovacími prvky (např. zasakování srážkových vod ze střech), jež se většinou nacházejí v určité hloubce několika metrů pod terénem, vesměs tedy pod půdním pokryvem. Ukázala se dobrá použitelnost nově definovaných hydrologických skupin půd, které je dělí do čtyř základních skupin A, B, C a D [8] [9]. Skupina A zahrnuje nejpropustnější půdy a má největší infiltrační potenciál, naopak skupina D znamená málo propustné půdy, jež znamenají překážku pro významnějši infiltraci. Nejpropustnější půdy písčitého charakteru jsou svázány s podložím pískovců a štěrkopísků, naopak málo propustné půdy se vyskytují na skalním podkladu břidlic, slínovců nebo vápenců.

5. Morfologie terénu je parametr, který má velký význam při hodnocení velkých územís dostatečnou tvarovou i výškovou diverzifikací, jež se odráží na variabilitě srážek a rychlosti povrchového odtoku. Krajina vnější Prahy má podobný charakter terénu a nachází se v podobné nadmořské výšce (180-390 m n. m.) [19]. Tento parametr proto nebyl k dalšímu hodnocení infiltračního potenciálu území využit.

Pro hodnocení vhodnosti území vnější Prahy k infiltraci tak byly využity tři okruhy dat:

- Charakter horninového prostředí s rozdělením hornin do pěti skupin podle infiltračního potenciálu. Syntetická data sestavená na základě digitální geologické mapy GeoČR [18] zahrnuji litologickou charakteristiku hornin saturované a nesaturované zóny (včetně zvětralinového pláště a kvartérního pokryvu), typ zvodnění a velikost propustnosti, v přesnosti zobrazení 1 : 50000 [15].

- Hydrologické skupiny pưd zahrnují rozdělení pưd do čtyř skupin podle infiltračního potenciálu v poslední dostupné verzi, zpracované podle metodiky VúMOP [9]. Údaje jsou k dispozici v měř́tku 1:5 000.

- Houbka hladiny podzemní vody, rozdělená do tř́ intervalů (0-2 m, 2-6 m a více než 6 m), odkazující (spolu s pórovitostí hornin) na volný zásobní objem pro infiltrovanou vodu. Data byla převzata z inženýrskogeologické mapy Prahy na portálu IPR Praha [17]. Údaje jsou k dispozici v měřítku 1: 5 000. Inženýrskogeologické mapy Prahy byly zpracovávány většinou v 80. letech 20. století. Pokles hladin podzemní vody, k němuž dochází v posledním období vlivem klimatických změn, se na území Prahy může projevovat především na vyvýšeninách, kde je hladina mnohem hlouběji než zde uvažovaných $6 \mathrm{~m}$, a naopak mělké hladiny jsou opřené o místní vodní toky, jejich větší změny proto nenastaly. Pokud někde lokálně došlo k mírným poklesům hladiny podzemní vody oproti využitým podkladům, je to pod mezí přesnosti dosažených syntetických výstupů.

Tyto tři skupiny údajů byly $v$ prostředí ArcGIS vhodně zkombinovány za vytvoření dvou syntetických map posuzujících různé aspekty vhodnosti území pro infiltraci:

- mapa infiltračního potenciálu půdního a horninového prostředí, kombinující první dvě vrstvy

- mapa infiltrační kapacity území, zdůrazňující i informace o volném zásobním objemu pro infiltrovanou vodu

\section{MAPA INFILTRAČNÍHO POTENCIÁLU}

Infiltrační potenciál znamená vhodnost půdního a horninového prostředí pro infiltraci srážkových a povrchových vod. Jde o syntetický výstup založený na kombinaci vrstev charakteru horninového prostředí a hydrologických skupin půd. Hodnocení je v zásadě založeno hlavně na propustnosti půdních a horninových vrstev, ale zahrnuje i další aspekty vycházející ze zastoupených půdních a horninových typů (pórovitost, typ zvodnění, vlhkost půd aj.).

Mapa je zobrazitelná pro celé území vnější Prahy (obr. 2) a její přesnost odpovídá měřítku regionálního zpracování 1 : 50 000. Výsledný infiltrační potenciál je zobrazen ve čtyřech třídách:

— vysoký infiltrační potenciál (zelená barva)

— zvýšený infiltrační potenciál (žlutá barva)

- nízký infiltrační potenciál (okrová barva)

— zanedbatelný infiltrační potenciál (červená barva) 
Z mapy na obr. 2 vyplývá, že většina území vnější Prahy má spíše nízký infiltrační potenciál a hodnoty vysokého a zvýšeného potenciálu se vyskytuji jen na omezených plochách (zelené a žluté barvy). O to větší pozornost je třeba věnovat jejich ochraně a důrazu na podporu vsakování srážek právě v nich.

Mapa umožňuje celkové hodnocení území a je využitelná např. pro širší územní plánování, např. v katastrálních územích. Pro hodnocení menších území, např. rozvojových ploch nebo jednotlivých pozemků, je třeba situaci upřesnit s využitím zdrojových vrstev a terénní rekognoskace.

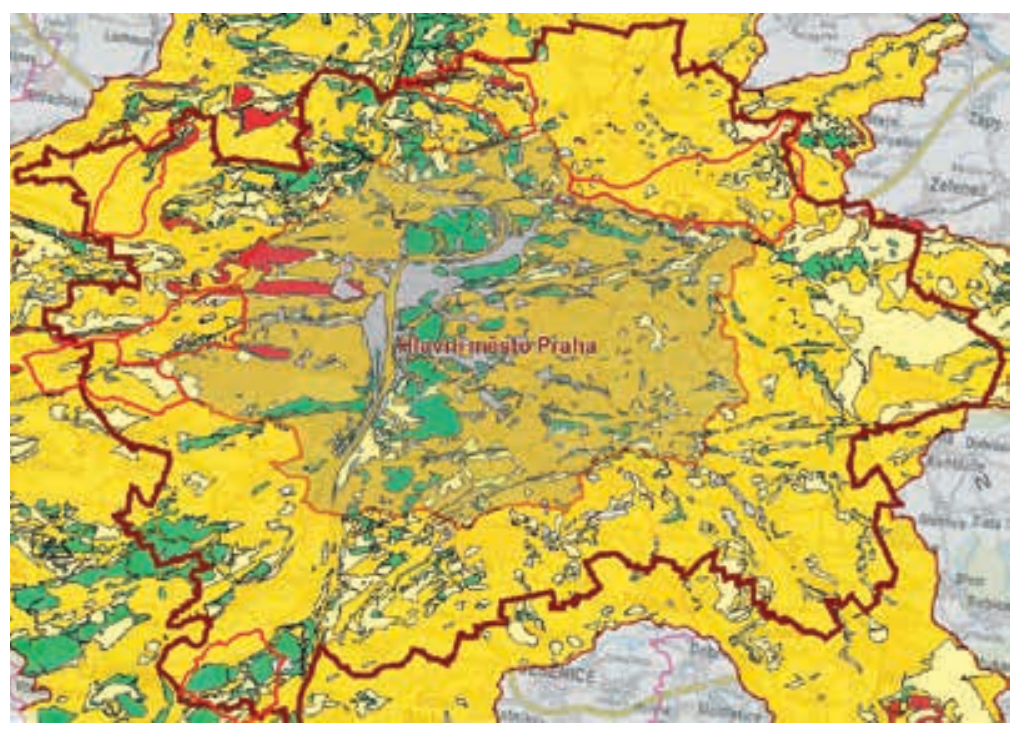

Obr. 2. Přehledná mapa infiltračního potenciálu na území prstence vnější Prahy [20].

Hranice Prahy zobrazena tmavočerveně, plochy pilotních povodí červeně. Tmavá oblast uprostřed ohraničená okrovou linií znázorňuje území, jež nebylo předmětem výzkumu (vnitřní Praha)

Fig. 2. An overview map of infiltration potential in the territory of outer Prague [20].

The border of Prague is shown in dark red, the areas of the pilot catchments in red lines.

Na obr. 3 je uveden detail infiltračního potenciálu v povodí Motolského potoka. I z něho je vidět, že na většině území převažuje prostředí s nízkým infiltračním potenciálem a jen několik ploch odkazuje na zvýšené a vysoké hodnoty (žluté a zelené barvy). Podpora infiltrace, výstavba vsakovacích prvků a územní ochrana by proto měla směřovat predevším do těchto částí povodí, protože účinnost přijatých opatření bude zde největší.

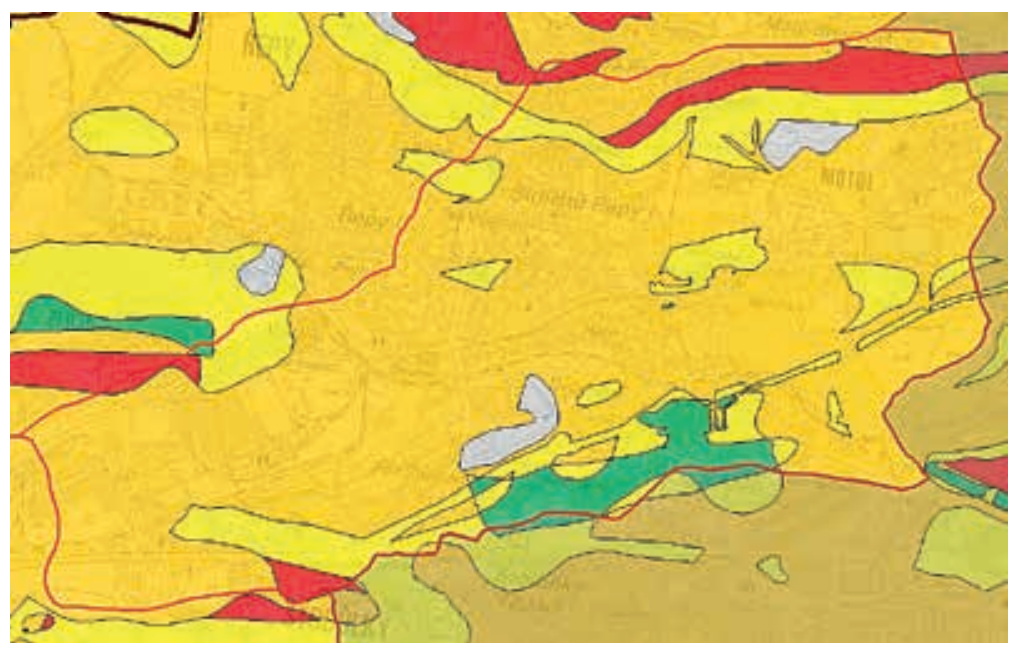

Obr. 3. Mapa infiltračního potenciálu povodí Motolského potoka [20]

Fig. 3. Map of the infiltration potential of the Motol stream catchment [20]

\section{MAPA INFILTRAČNI KAPACITY}

Zavedený parametr infiltrační kapacita znamená syntetické hodnocení území zdůrazňující - vedle infiltračního potenciálu - hloubku hladiny podzemní vody, která odkazuje na volný zásobní prostor pro infiltrovanou vodu. Mapa tedy kombinuje všechny tři skupiny údajů, a to v poměru $1: 1: 2$ ve prospěch parametru hloubky hladiny podzemní vody. Existence volného zásobního objemu je totiž zásadním předpokladem úspěšnosti intenzifikace zasakování srážkových vod v území.

Mapa infiltrační kapacity byla zpracována pouze v plochách šesti pilotních povodí. Její rozširrení na celou plochu vnější Prahy je závislé na postupu časově náročné digitalizace údajů o hladině podzemní vody, jež jsou zatím k dispozici na většině území jen v rastrové formě (inženýrskogeologické mapy Prahy na portálu IPR Praha [17]). Vzhledem k významu tohoto parametru však doporučujeme $v$ brzké době realizaci těchto prací, které by měly zahrnovat nejen digitalizaci rastrových map, ale i jejich aktualizaci ve formě terénního ověření na dostupných bodech a prípadnou úpravu pưvodních hydroizohyps.

Výsledná infiltrační kapacita území je zobrazena ve čtyřech tříách:

— vysoká infiltrační kapacita (zelená barva)

— zvýšená infiltrační kapacita (žlutá barva)

- nízká infiltrační kapacita (okrová barva)

— zanedbatelná infiltrační kapacita (červená barva)

Obr. 4 ukazuje detail s hodnotami infiltrační kapacity v povodí Motolského potoka. Pokud tuto mapu porovnáme s mapou infiltračního potenciálu na obr. 3, vidíme, že po stránce infiltrační kapacity je situace mnohem príznivější; v povodí převažují žluté a zelené barvy, tzn. zvýšená až vysoká infiltrační kapacita. Z rozdílných hodnocení území obou map vyplývá, že volný zásobní prostor pro vsakovanou vodu v povodí Motolského potoka je významný, propustnost hornin umožňující dobrý vsak srážek však není optimální. Opatření pro podporu vsaku je zde žádoucí dodržovat, ale za zvýšené pozornosti správnému umístění vsakovacích prvků a jejich optimální konstrukci.

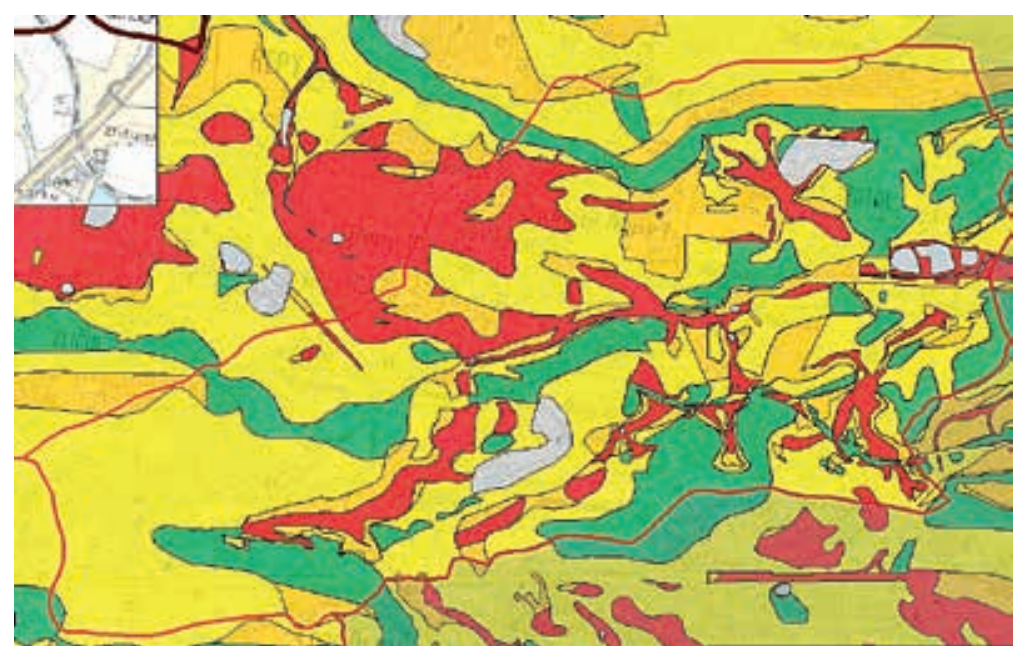

Obr. 4. Mapa infiltrační kapacity povodí Motolského potoka [20]

Fig. 4. Map of the infiltration capacity of the Motol stream catchment [20]

Infiltrační kapacitu území lze orientačně odhadnout i v dalších oblastech vnější Prahy, kde je k dispozici mapa infiltračního potenciálu. Pokud existují z území zájmu informace o hloubce hladiny podzemní vody (např. z rastrových inženýrskogeologických map, z měření místní studny, z průzkumného vrtu apod.), infiltrační kapacita může být posunuta nahoru i dolů o jednu třídu oproti infiltračnímu potenciálu. Např. pokud budeme mít dvě území se zvýšeným infiltračním potenciálem (žlutá barva), ale v jednom území bude hladina 
ve $2 \mathrm{~m}$ pod terénem a ve druhém území v $8 \mathrm{~m}$ pod terénem, první území bude mít nízkou infiltrační kapacitu (oranžová barva), zatímco druhé území bude mít vysokou infiltrační kapacitu (zelená barva).

\section{VLIV ZÁSTAVBY A VYUŽITÍ ÚZEMÍ}

Reálná infiltrace srážek do podzemních vod je však ovlivňována nejen prírodními podmínkami, ale i charakterem využívání území. Mapy infiltračního potenciálu a infiltrační kapacity je proto vhodné kombinovat s mapou využití území (např. ZABAGED, CORINE [19] [21]). Zatravněné oblasti (louky, pastviny, zahrady, parky), případně další části volné krajiny tvoří ideální plochy umožňující maximální možnou infiltraci. Na druhé straně jsou území s hustou zástavbou s velkými budovami, sklady, nepropustnými povrchy významných dopravních staveb, parkovišt apod., kde je infiltrace snížená na minimum. A mezi těmito krajními variantami využití krajiny jsou ostatní způsoby jejího využívání, jež jsou více či méně šetrné pro udržení potenciálu území k infiltraci - rozptýlená či kompaktní zástavba se zahradami, extenzivní zemědělské a průmyslové areály různé velikosti, plochy navážek a skládek aj.

\section{PODPORA INFILTRACE SRÁŽKOVÝCH VOD}

Možnost podpory infiltrace a pozitivního ovlivnění tvorby podzemní vody se týká především doposud volných ploch krajiny, kterých však na území vnější Prahy rychle ubývá vlivem intenzivní výstavby obytných budov, průmyslových areálů, dopravních staveb apod. Realizovatelná opatření se rozpadají do několika skupin:

- Zajistit ochranu území s vysokým a zvýšeným infiltračním potenciálem a infiltrační kapacitou před zbytečnou zástavbou, nešetrnou k ochraně hydrologického cyklu.

- Pokud bude v těchto územích nutné jakoukoli výstavbu realizovat, zachovat v maximální možné míre plochy k infiltraci srážkových vod.

— Trvat v těchto územích na důsledném zasakování srážkových vod ze střech a zabránit zbytečnému odtoku srážkových vod kanalizací a drenážemi mimo území.

- Potřebnou zástavbu směřovat spíše do území s nízkým a zanedbatelným infiltračním potenciálem.

- Netrvat na zasakování srážkových vod v nevhodném území s nízkým nebo zanedbatelným infiltračním potenciálem či infiltrační kapacitou. A naopak se pokusit kreativně posunout místo vsakování do blízkého území s vhodnějšími infiltračními parametry, pokud je to možné.

\section{ZÁVĚR}

Předložený článek upozorňuje na problematiku omezené tvorby podzemní vody $\vee$ urbanizovaných územích. Negativní dopady klimatických změn jsou tam navíc zhoršovány i omezováním infiltrace srážek v důsledku antropogenni činnosti (zástavba území, nepropustné plochy aj.). Na základě výzkumu realizovaného v území vnější Prahy, kde dochází k intenzivní zástavbě dosud volné krajiny, vznikla metodika hodnocení vhodnosti území k infiltraci srážek do podzemních vod. Pro detailní posouzení hydrologických a hydrogeologických poměrů bylo využito šest pilotních povodí (Kopaninský potok, horní část Motolského potoka, Dalejský potok, Lipanský potok, Vinořský potok a Drahanský potok).

Východiskem prací byla metodika hodnocení zranitelnosti podzemní vody, známá jako metoda DRASTIC [12] [13] [14], která je celosvětově rozšířená v množství rưzných aplikací hodnotících podzemní vody, jejich ochranu a zranitelnost. $\checkmark$ obou prípadech jde totiž o hodnocení velmi podobných parametrů půdního a horninového prostředí.
Po zhodnocení všech dostupných podkladů byly pro území vnější Prahy využity tři okruhy dat: charakter horninového prostředí nesaturované a saturované zóny, hydrologické skupiny půd a hloubka hladiny podzemní vody. První dvě skupiny dat byly k dispozici v digitální formě v celé ploše území vnější Prahy, hloubka hladiny byla ale $k$ dispozici jen v rastrové formě. V ploše pilotních povodí a jejich blízkém okolí byly proto údaje o hladině podzemní vody zdigitalizovány, nebylo však v silách tohoto projektu zajistit digitalizaci v celé ploše vnější Prahy. Kombinací těchto údajů vznikly dvě syntetické mapy: mapa infiltračního potenciálu půdního a horninového prostředí, kombinující první dvě vrstvy, a mapa infiltrační kapacity území, zdưrazňující - na základě hloubky hladiny - i informace o volném zásobním objemu pro infiltrovanou vodu [20].

Mapa infiltračního potenciálu je dostupná pro celé území vnější Prahy, mapu infiltrační kapacity bylo možné zpracovat jen pro plochy pilotních povodí, kde se podařilo zdigitalizovat údaje o hloubce hladiny. Přesnost map odpovídá měřítku regionálního zpracování 1 : 50 000. Kombinací těchto map a map zástavby, prípadně využití území (např. ZABAGED nebo CORINE [19] [21]), je možné provést komplexní hodnocení krajiny z hlediska infiltrace srážek a zvolit v ní optimální opatření k podpoře infiltrace.

Z možných dalších činností na pokračování projektu doporučujeme vytrvat v časově náročné práci na digitalizaci rastrových map hloubky hladiny podzemní vody v ploše prstence vnější Prahy, jež by měla zahrnovat i kompletaci těchto dat na celém území hlavního města a rovněž jejich aktualizaci ve formě terénního ověření na dostupných bodech (studny, vrty) z důvodu postupného zastarávání původního podkladu - inženýrskogeologických map Prahy.

Metodiku Ize dobře použít i v jiných urbanizovaných oblastech ČR. Vrstva charakteru horninového prostředí i hydrologických skupin půd je $k$ dispozici v celé ploše ČR a jejich kombinací lze vytvořit mapu infiltračního potenciálu jakéhokoli území. Podobně celoplošně jsou dostupné i rưzné mapy využití území ([19] [21]). Explicitní informace o hloubce hladiny podzemní vody ke konstrukci mapy infiltračního potenciálu sice mnohdy k dispozici nejsou, avšak tyto údaje Ize pro většinu území ČR zjistit na základě hydrogeologické a vrtné prozkoumanosti (archiv ČGS - Geofond), případně je možné je aspoň odhadnout na základě odborného hydrogeologického posouzení.

Vytvořené mapy jsou veřejně prístupné v prohližečce mapové aplikace projektu Analýza adaptačních opatření ke zmírnění dopadů změny klimatu a urbanizace na vodní režim v oblasti vnější Prahy, rešeného v rámci Operačního programu Praha - pól růstu ČR na webových stránkách heis.vuv.cz/projekty/praha-adaptacniopatreni [20].

Na toto téma vznikla i populárně naučná publikace Podzemní voda ve městě [1], jež je dostupná ve Výzkumném ústavu vodohospodářském T. G. Masaryka, v. v. i., v tištěné formě i v elektronické podobě ve formátu PDF na webových stránkách projektu [20], a to včetně anglické verze [22]. Je součástí tříílné série, jež obsahuje tyto tituly: Město a voda, Podzemní voda ve městě a Adaptace města na povodně a sucho (i zbývající dvě publikace jsou k dispozici v české a anglické verzi ve formátu PDF na stránkách projektu [20]). K rozšíření znalostí o podzemní vodě vznikl rovněž výukový portál pro žáky, studenty i širokou neodbornou veřejnost, který lze nalézt také na výše uvedených webových stránkách [20].

Závěrem ještě upozorňujeme, že danou problematikou se zabývají i některé jiné projekty, např. na platformě inženýrskogeologických map postupně začíná vznikat vsakovací mapa Prahy, primárně jako podklad pro hospodaření s deštovými vodami [23].

\section{Poděkování}

Tento článek byl pripraven v rámci projektu "Analýza adaptačních opatření ke zmirněni dopadů změny klimatu a urbanizace na vodní režim v oblasti vnější Prahy", č. CZ.071.02/0.0/0.0/16-040/0000380, financovaného z Operačního programu Praha pól rưstu ČR, a projektu „Řizená dotace podzemních vod jako nástroj k omezení dopadů sucha v ČR", č. SS01010208, podpořeného Technologickou agenturou ČR. 


\section{Literatura}

[1] DATEL, J. V. Podzemní voda ve městě. Praha: VúV TGM, v. v. i., 2020, 44 s. ISBN 978-80-87402-86-3.

[2] CHLUPÁĆ, I. Vycházky za geologickou minulostí Prahy a okolí. Praha: Academia, 1999, $280 \mathrm{~s}$. ISBN 80-200-0680-X.

[3] NĚMEC, J., LOŽEK, V. et al. Chráněná území ČR 2 Praha. Praha: Consult a AOPK ČR, 1997, $156 \mathrm{~s}$. ISBN 80-902132-1-9.

[4] OLMER, M. et al. Hydrogeologická rajonizace České republiky. Sborník geologických věd. Hydrogeologie, Inženýrská geologie, 23. Praha: ČGS, 2006, 32 s. ISBN 80-7075-660-8.

[5] KRÁSNÝ, J. et al. Odtok podzemní vody na území Československa. Praha: ČHMÚ, 1982, $52 \mathrm{~s}$

[6] @Hydroekologický informační systém HEIS. Praha:VúV TGM, v. v. i., 2020. Dostupné z: https://heis.vuv.cz/ [7] KRÁSNÝ, J. et al. Podzemní vody České republiky: Regionální hydrogeologie prostých a minerálních vod. Praha: Česká geologická služba, 2012, 1144 s. ISBN 978-80-7075-797-0.

[8] @USDA NRSC. National Engineering Handbook, Part 630 Hydrology, chapter 7. Washington, DC: United States Department of Agriculture, Natural Resources Conservation Service, 2009. Dostupné z: https:// directives.sc.egov.usda.gov/OpenNonWebContent.aspx?content=22526.wba.

[9] VOPRAVIL, J. et al. Mapové vymezení infiltračnich schopností a propustnosti zemédělských a nezemědělských půd ČR s celorepublikovou územni kategorizaci Praha: VúMOP 2018. Osvědčení c. 8/14130-MZe-2018

[10] MARGAT, J. Vulnérabilité des nappes d'eau souterraine a la pollution (Groundwater vulnerability to contamination). Bases de la cartographie, (Doc.) Orléans. France: BRGM, 1968, SGL 198 HYD

[11] US National Research Council. Ground water vulnerability assessment: contamination potential under conditions of uncertainty. - Committee on Techniques for Assessing Ground Water Vulnerability. Water Science and Technology Board. USA, 1993.

[12] VRBA, J., ZAPOROZEC, A. EDS. Guidebook on mapping groundwater vulnerability. International Contributions to Hydrogeology, vol. 18. Hannover, Germany: Heise, 1994, 131 s.

[13] ALLER, L. et al. DRASTIC: A Standardized System for Evaluating Ground Water Pollution Potential using Hydrogeologic Settings. Environmental Research Laboratory. Ada, Oklahoma: US EPA, 1985, 641 s. EPA 600/2-85-018

[14] ALLER, L. et al. DRASTIC: A Standardized System for Evaluating Ground Water Pollution Potential using Hydrogeologic Settings. Ada, Oklahoma: US EPA, 1987, 641 s. EPA 600/2-87-035

[15] NOVÁK, P., SLAVÍK, J. et al. (2012): Syntetická mapa zranitelnosti podzemních vod. Praha a Brno: VÚMOP, v. v. i. a GEOtest, a.s., 2012, 44 s. ISBN 978-80-87361-19-1.

[16] HRKAL, Z. et al. Metodika hodnocení území České republiky z hlediska vhodnosti pro řizenou dotaci podzemnich vod vodami povrchovými a možností umělé infiltrace vyčištěných odpadních vod a aplikace této metodiky na územi ČR. MS. Praha: Vúv TGM, v. v. i., 2010, 387 s.

[17] @ IPR Praha. Mapový portál - Inženýrskogeologické mapy Prahy 1:5 000. Dostupné z: http://app. iprpraha.cz/apl/app/ig_mapy/. Praha: Institut plánování a rozvoje hl. m. Prahy a ČÚZK, 2020

[18] ๔ ČGS. Mapový portál - Soubor geologických map GeoČR 1 : 50 000. Podklady z období 1985-2000. Dostupné z: https://mapy.geology.cz/geocr50/. Praha: Česká geologická služba, 2020

[19] ๑ ČÚZK. Geoportál ČÚZK - ZABAGED a státnímapa ČR. https://geoportal.cuzk.cz/. Praha: ČÚZK, 2020 [20] @ HRABÁNKOVÁ, A. et al. „Analýza adaptačních opatření ke zmírnění dopadů změny klimatu a urbanizace na vodní režim v oblasti vnější Prahy“. [Stránky projektu OP Praha-pól růstu] Dostupné z: heis.vuv.cz/projekty/praha-adaptacniopatreni. Praha: VúV TGM, v. v. i., 2020

[21] @ EUROPEAN UNION. Copernicus Land Monitoring Service 2018, CORINE. Dostupné z: https://land. copernicus.eu/. Copenhagen, Denmark: European Environment Agency (EEA), 2020

[22] DATEL, J. V. Groundwater in the City. Praha: T. G. Masaryk Water Research Institute, public research institution, 2020, 44 s. ISBN 978-80-87402-87-0.

[23] ๑ JKENVI. Vsakovaci mapy na území hlavního města Prahy 1:5000. Praha: JKENVI, 2020. Dostupné z: https://www.jkenvi.cz.

\section{Autoři}

RNDr. Josef Vojtěch Datel, Ph.D.

凶josef.datel@vuv.cz

ORCID: 0000-0003-1451-0135

Ing. Anna Hrabánková

凶anna.hrabankova@vuv.cz

ORCID: 0000-0003-1631-0700
Ing. Luděk Strouhal, Ph.D.

凶ludek.strouhal@vuv.cz

ORCID: 0000-0002-3979-4894

Výzkumný ústav vodohospodářský T. G. Masaryka, v. v. i.

Přispěvek prošel lektorským řízením.

DOI: 10.46555/VTEI.2021.01.006

\section{GROUNDWATER FORMATION \\ IN URBAN AREAS REGARDING PERIPHERAL PARTS OF PRAGUE}

\section{DATEL, J. V.; HRABANKOVA, A.; STROUHAL, L.}

\author{
T. G. Masaryk Water Research Institute, p. r. i.
}

Keywords: groundwater - infiltration - Prague - urbanization

Groundwater is an integral part of the hydrosphere and hydrological cycle in a healthy landscape, which is better able to withstand hydrological extremes such as floods or prolonged drought. The main source of groundwater is precipitation. There are a number of barriers for infiltration in urban areas - urban and industrial buildings, as well as increasing areas with impermeable surfaces. The aim of the paper is to draw attention to the importance of groundwater in the urban landscape and to possible measures to support the infiltration of precipitation.

The research took place in the territory of outer Prague, where there is an intensive expansion of the built-up area, which is accompanied by a lower infiltration of precipitation, compared to the open landscape. Based on the evaluation of pedological, geological and hydrogeological conditions of the area, a methodology for evaluating the suitability of the area for infiltration was developed. Based on it, two types of maps were created: an infiltration potential map evaluating primarily the permeability of the soil and rock environment, and an infiltration capacity map, in addition emphasizing the size of the free storage volume for infiltrated water. Maps are available for viewing in the map application on the project website heis.vuv.cz/projekty/praha-adaptacniopatreni.

It is advisable to work with these maps in combination with the current development map or the map of complex land use, in order to choose the optimal measure to support the infiltration in each area. These measures include protection of areas with increased suitability for infiltration before construction, reduction of water drainage by rain sewers, differentiated support of rainwater infiltration (e.g. from roofs) according to the infiltration suitability of different areas, etc. 